Georgia State University

ScholarWorks @ Georgia State University

3-1-2014

\title{
Charter High Schools' Effects on Long-Term Attainment and Earnings
}

Kevin Booker

Mathematica Policy Research

Brian Gill

Mathematica Policy Research

Tim Sass

Georgia State University

Ron Zimmer

Vanderbilt University

Follow this and additional works at: https://scholarworks.gsu.edu/uwrg_workingpapers

\section{Recommended Citation}

Booker, Kevin; Gill, Brian; Sass, Tim; and Zimmer, Ron, "Charter High Schools' Effects on Long-Term Attainment and Earnings" (2014). UWRG Working Papers. 82.

https://scholarworks.gsu.edu/uwrg_workingpapers/82

This Article is brought to you for free and open access by the Usery Workplace Research Group at ScholarWorks @ Georgia State University. It has been accepted for inclusion in UWRG Working Papers by an authorized administrator of ScholarWorks @ Georgia State University. For more information, please contact scholarworks@gsu.edu. 


\section{W. J. Usery Workplace Research Group Paper Series}

Working Paper 2014-3-1

March 2014

\section{Charter High Schools' Effects on Long- Term Attainment and Earnings}

Kevin Booker

Mathematica Policy Research

Brian Gill

Mathematica Policy Research

Tim Sass

Georgia State University

Ron Zimmer

Vanderbilt University 


\title{
Charter High Schools' Effects on Long-Term Attainment and
}

\section{Earnings}

\author{
Kevin Booker \\ Mathematica Policy Research \\ Brian Gill \\ Mathematica Policy Research \\ Tim Sass \\ Georgia State University \\ Ron Zimmer \\ Vanderbilt University
}

February 2014

\begin{abstract}
:
Since their inception in 1992, the number of charter schools has grown to more than 6,000 in 40 states, serving more than 2 million students. Various studies have examined charter schools' impacts on test scores, and a few have begun to examine longer-term outcomes including graduation and college attendance. This paper is the first to estimate charter schools' effects on student earnings, alongside effects on educational attainment. Using data from Chicago and Florida, we find evidence that charter high schools may have substantial positive effects on persistence in college as well as high-school graduation and college entry. In Florida, where we can link students to workforce data in adulthood, we also find evidence that charter high schools produce large positive effects on subsequent earnings.
\end{abstract}




\section{Introduction}

Charter schools - publicly funded schools of choice that operate outside the direct control of traditional school districts - have grown rapidly since their inception two decades ago. More than 6,000 schools operate in more than 40 states, serving over 2 million students. Most of the research on charter schools' efficacy has focused on short-term effects on student test scores. This paper makes new contributions to a much thinner literature on the longer-term effects of charter schools. Using longitudinal data from Chicago and Florida, this study extends our prior research (Booker, Sass, Gill, \& Zimmer, 2011) on the effects of attending charter schools on educational attainment, and it is the first study to estimate the long-term effects of charter schools on earnings in adulthood.

Studies of charter schools' test score impacts have covered a wide variety of jurisdictions. Some have used quasi-experimental methods with longitudinal data (e.g., Zimmer, Gill, Booker, Lavertu, \& Witte, 2012; Furgeson et al., 2012; Zimmer et al., 2009; Davis \& Raymond, 2012; Booker, Gilpatric, Gronberg, \& Jansen, 2007; Hanushek, Kain, Rivitch, \& Branch, 2007; Bifulco \& Ladd, 2006; Sass, 2006; Zimmer \& Buddin, 2006; Zimmer et al., 2003). Others have employed experimental approaches using data from admission lotteries (Furgeson et al., 2012; Gleason, Clark, Tuttle, \& Dwoyer, 2010; Abdulkadiroglu, Angrist, Dynarski, Kane, \& Pathak, 2011; Angrist et al., 2011; Hoxby \& Rockoff, 2004; Hoxby \& Murarka, 2009). The findings from this research are mixed. The totality of evidence could be read as suggesting that any difference in average performance of charters and traditional public schools across the country is probably small; however, it is clear that some types of charter schools (for example, KIPP and other "no-excuses" charter schools serving disadvantaged urban students) significantly and 
substantially improve their students' test scores (Angrist et al., 2011; Tuttle et al., 2013; Dobbie \& Fryer, 2011).

Outcomes such as high school graduation, college enrollment and persistence, and earnings are ultimately of greater consequence than test scores. The financial advantage associated with a college education has long been recognized (Day \& Newburger, 2002); in recent years, however, its value has become increasingly apparent, as manufacturing jobs have vanished and the wages of high school educated workers have stagnated. Even as the cost of higher education has increased substantially, the value of a degree has continued to grow. Recognizing this, the Obama administration and other policymakers and funders have sought to increase access to college and improve students' readiness for college.

Recognizing the importance of college, a few recent studies have used postsecondary enrollment as an outcome to evaluate the impact of a variety of K-12 educational policies (Deming et al., 2013; Bettinger et al., 2012; Chingos \& Peterson, 2012; Richburg-Hayes et al., 2009; Chetty, Friedman, \& Rockoff, 2011). Compared to the voluminous literature on achievement effects, research on the impact of charter schools on educational attainmentincluding high school graduation, college attendance, and college persistence—is still sparse. Our own prior study (Booker et al., 2011) was the first to examine attainment outcomes associated with charter schools; a few other studies have followed its example. We found that students attending Chicago and Florida charter high schools were 7 to 15 percentage points more likely to graduate and 8 to 10 percentage points more likely to enroll in college than comparison groups of students who attended charter middle schools but matriculated to traditional public high schools. Subsequently, Furgeson et al. (2012) found evidence that impacts on high school graduation and college entry vary in different charter school management organizations (CMOs), 
but that some CMOs appeared to produce substantial positive attainment impacts. Angrist, Cohodes, Dynarski, Pathak, and Walters (2013), relying on randomized admissions lotteries, found that Boston charter high schools had positive impacts on measures of college preparation (such as SAT scores), no statistically significant impact on high school graduation, and an effect of shifting students from two-year colleges into four-year colleges. ${ }^{1}$ Another study (Dobbie \& Fryer, 2013) found significantly positive attainment impacts, but it examined only one charter school.

The findings of these studies are intriguing, but they also raise additional questions. In particular, how should policymakers, parents, and citizens interpret positive attainment results when many studies - including our own studies of charter schools in Chicago and Florida (Sass, 2006; Zimmer et al., 2012)— have shown little or no effect on test scores? Skeptics could argue that positive effects on graduation and postsecondary attendance could be illusorily if schools are setting lower graduation standards and not actually preparing their students for college or employment. Alternatively, charter schools might produce larger effects on attainment than on test scores because they are endowing students with skills, knowledge, work habits, motivation, and values that are important for long-term success but are not fully captured by test scores.

\footnotetext{
${ }^{1}$ Other studies have estimated impacts of non-charter schools that are similar to charters in some respects. Bloom and Unterman (2013) found that students attending small high schools with choice-based admission had a 9.5 percent increased likelihood of graduating from high school. Similarly, Sander and Krautmann (1995), using data from 1980 High School and Beyond surveys, found Catholic high school attendance is associated with a 10 percentage point reduction in the high school dropout rate. Evans and Schwab (2005), who also used the 1980 High School and Beyond data, estimated that Catholic high school attendance raises the probability of high school graduation 12 to 13 percentage points and increases the likelihood of college attendance by 11 to 13 percentage points. Based on National Longitudinal Survey of Youth (NLSY)79 data, Neal (1997) found that Catholic high school attendance boosts the probability of graduating from high school 16 percentage points for urban minorities and 10 percentage points for whites in urban areas. Grogger and Neal (2000), using National Educational Longitudinal Study (NELS) data from 1988-1994, found even larger effects. They estimated that Catholic high school attendance is associated with an 18 percentage point increase in expected graduation rates for urban minorities and a 17 percentage point increase in the likelihood of college attendance for all minority students. More recently, Wolf et al. (2013) used randomized admissions lotteries and found that using a Washington, DC, voucher increases graduation rates by 21 percentage points. Chingos and Peterson (2012) also used a lottery-based approach and found that using a voucher to attend a private school in New York City increased college enrollment among African American students by 8 percentage points.
} 
Notably, no studies have attempted to measure the effect of charter schools on eventual earnings in adulthood.

This paper extends the literature by going beyond graduation and postsecondary admission rates to examine whether students who attended charter high schools are more likely to persist in postsecondary institutions and, ultimately, achieve higher earnings. We use the same general research design that we used in our previous study to address the potential selection bias problem inherent in studies of schools of choice. Lacking data on randomized admissions lotteries, we restrict our attention to a sample of students who were enrolled in charter schools in eighth grade. The treatment students in our analysis remained enrolled in charter schools in ninth grade; the comparison students switched to conventional public schools. The counterfactual condition, in other words, is represented by students who also had once chosen to enroll in charter schools rather than by students who had never chosen charter schools. We also address selection by controlling for baseline student characteristics (including eighth-grade test scores) and by conducting a sensitivity analysis that uses the distance to the nearest charter high school as an instrument for enrollment.

In our previous study of charter high schools in Chicago and Florida, the schools had not been operating long enough to permit us to follow a sufficient sample of charter graduates beyond initial college entry. In this paper, we incorporate several additional years of data, giving us a long enough time period to examine whether students are accumulating years of postsecondary education. In addition, in Florida, we examine the labor outcomes of students who are up to 12 years removed from the eighth-grade baseline year (that is, around ages 23 to 25). Therefore, this study not only provides new evidence of the effect of charter schools on persistence in college, but it also yields the first evidence on the effects of charter schools on 
earnings in adulthood. We find some evidence suggesting that charter high schools are not only increasing postsecondary educational attainment but also boosting long-run earnings.

\section{Methods}

Determining the impact of charter high schools is not easy, due to the inherent selection problem implicit in any study of school choice: students who select into charter high schools may be different in ways that are not readily observable from those who choose to attend traditional public high schools. The fact that the charter students and their parents actively seek an alternative to traditional public schools suggests the students may be more motivated or their parents may be more involved in their child's education than are the families of traditional public school attendees. Alternately, the students may be those who are having difficulty in traditional public schools. These characteristics are likely to affect later student outcomes, making it difficult to distinguish the effect of the school from the effect of underlying (and typically unobservable) student characteristics.

The two methods most commonly used to deal with selection bias in school choice impact studies-experimental methods using randomized admissions lotteries and nonexperimental, longitudinal approaches using pretreatment measures of the outcome of interestare not available to us. Lottery-based studies (see, for example, Gleason et al., 2010; Angrist et al., 2013; Hoxby \& Murarka, 2007) identify oversubscribed schools that use randomized admissions lotteries to allocate scarce spaces among applicants. Admissions lottery results are not available in our data. Even if they were available, prior experience (Tuttle, Gleason, \& Clark, 2012; Furgeson et al., 2012; Tuttle et al., 2013) demonstrates that they could be used to create valid experimental treatment and control groups in only a small percentage of the schools, 
dramatically reducing statistical power and raising questions about external validity (see also Abdulkadiroglu et al., 2011; Bifulco, Cobb, \& Bell, 2009; Zimmer \& Engberg, 2013).

The longitudinal approach using pretreatment measures of the outcomes of interest is often useful in examining impacts on test scores because, in reading and math, students typically take tests repeatedly over many years. The change in test scores for individual students who move between traditional public schools and charters can be used to infer the impacts of the charter schools on student achievement, while holding student/family characteristics constant. Two recent studies (Furgeson et al., 2012; Tuttle et al., 2013) have demonstrated that longitudinal analyses of test score impacts that control for pretreatment test scores can closely replicate randomized experimental impact estimates for the same students. But this approach cannot be used to measure long-term outcomes such as graduation, college enrollment, college persistence, and employment, because those outcomes do not occur before a student's enrollment in a charter school.

With the usual approaches unavailable, we use other strategies to deal with selection bias. The first involves identifying a comparison group. In all analyses, we restrict the sample to students who attended a charter school in grade 8 , just before beginning high school. The motivation for this is that unmeasured student/family characteristics that lead to the selection of charter high schools are also likely to be related to the choice of a charter school at the middle school level. This is the same approach that Altonji, Elder, \&Taber (2005) take to assess the attainment effects of Catholic high schools. The approach potentially limits the external validity of the results, because effects on charter high school students who attended charter middle schools might differ from effects on charter high school students who did not attend charter middle schools. Sacrificing some external validity is worthwhile to promote internal validity. 
Still, using a comparison group of charter middle school students might not fully deal with selection bias if there are important differences in the factors that drive selection into charter middle schools versus charter high schools.

In addition to matching students on middle school charter attendance, we deal with high school specific selection issues by controlling statistically for any observable differences in charter and non-charter high school students before high school entry. These include factors such as race/ethnicity, gender, prior mobility, disability status, and family income. Most important is the use of eighth-grade test scores to capture differences in student ability and past educational inputs received before high school. These models are formalized in equation 1 , where $A$ represents the outcomes, $C$ is a dichotomous indicator of whether the student attends a charter school, and $X$ is a vector of baseline observable characteristics, including eighth-grade test scores. When the outcome measure is dichotomous (high school graduation, college attendance, or college accumulation), we use a probit. When the outcome is continuous (labor earnings), we use ordinary least squares (OLS). In all analyses, we cluster the standard errors by the high school ID to account for the lack of independence among observations within schools.

$$
A^{*}=\beta_{2}^{\prime} X_{2}+\gamma C+u_{2}
$$

It is still possible that unobservable factors exist that are specifically related to selection into charter high schools and that are not correlated with observable characteristics. We seek to address selection on unobservables by applying, in a sensitivity analysis, a two-stage, instrumental variable (IV) analysis that exploits variation in the location of charter high schools (relative to the charter middle schools the students attended) to predict charter high school enrollment (following the approach of Neal [1997] and Grogger and Neal [2000] in their analyses of Catholic high schools). This plays out in two ways. First, some charter schools offer 
both middle and high school grades, effectively making the transition cost zero. ${ }^{2}$ A charter middle school student is more likely to attend a charter high school if he or she can stay in the same school for high school grades. Second, when a student must switch schools to attend high school, distance can vary greatly; the nearest charter high school could be down the street or many miles away. Proximity to a charter high school should make it more likely that a student will attend a charter high school.

Depending on whether the outcome is dichotomous or continuous, we use a bivariate probit or IV approach, both of which use proximity to charter schools as an instrument for charter high school enrollment.

Consider the following bivariate probit:

$$
\begin{aligned}
& C^{*}=\beta_{1}^{\prime} X_{1}+u_{1} \\
& A^{*}=\beta_{2}^{\prime} X_{2}+\gamma C+u_{2}
\end{aligned}
$$

where $C^{*}$ and $A^{*}$ are latent variables and $X_{1}$ and $X_{2}$ are vectors of exogenous variables. We observe the binary choice, $C$, indicating charter high school attendance, where $C=1$ if $C^{*}>0$ and $C=0$ if $C^{*} \leq 0$. Likewise, we observe the binary outcome, $A$ (attainment of a high school diploma, college attendance, or college persistence, as applicable), where $A=1$ if $A^{*}>0$ and $A=$ 0 if $A^{*} \leq 0$. The error terms, $u_{1}$ and $u_{2}$, are distributed as bivariate normal with mean zero, unit variance and correlation coefficient $\rho$. In our analysis of labor market outcomes, the dependent variable, earnings $(E)$, is continuous:

$$
E=\beta_{3}^{\prime} X_{3}+\delta C+u_{3}
$$

\footnotetext{
${ }^{2}$ Although many charter schools offering middle and high school classes have all grades in the same location, not all do. In some instances, there can be one common administration, but the high school campus may be physically separate from the middle school campus.
} 
We therefore employ the IV method suggested by Wooldridge (2002), in which the fitted probabilities from equation (2), $\hat{C}$, along with the other exogenous variables, $X_{3}$, are used as instruments for $C$ in a standard two-stage least squares estimation of equation (4).

Finally, in both the bivariate probit and the IV procedures, we test for endogeneity of charter high school attendance. In the bivariate probit, we test whether rho, the correlation between the error of the educational attainment equation and the error of the selection equation, is non-zero. In the IV regression of earnings, we conduct a " $\mathrm{C}$ test" (which is similar to a Hausman test, but allows for clustering of the standard errors [Baum, Schaffer, \& Stillman, 2003]) to determine whether the IV estimates differ significantly from the OLS estimates. In both cases, there is no evidence of a difference in the probit/OLS estimates and bivariate/IV estimates, which provides some evidence that the univariate probit and OLS estimates should be unbiased. We therefore present our univariate probit and OLS estimates as our primary results in the main text and present the bivariate probit and IV estimates as a robustness check in Appendix A. The conclusions drawn from the bivariate probit and IV estimates are substantively consistent with the univariate and OLS estimates.

\section{Data}

Studying effects of K-12 interventions on long-term outcomes demands linked data on individual students from K-12 program participation through postsecondary enrollment, postsecondary persistence, employment, and earnings. Even when links are available to connect K-12 data with postsecondary and earnings data, a long time series is needed; studying the longterm effects of a high school intervention requires pre-high school data back to eighth grade and post-high school information into college and beyond. In addition, the jurisdiction studied must 
have a sufficient sample of students participating in the intervention (and a sufficient sample of comparison students) to provide reliable results. The areas we analyze, the state of Florida and the city of Chicago, are two of perhaps a handful of places where all the necessary data elements are currently in place. The two jurisdictions differ in many important respects, including region of the country, degree of urbanicity, racial/ethnic mix of students, and the policies governing charter schools. Including two such widely divergent jurisdictions in the study helps in assessing the generalizability of the findings.

\section{A. Florida}

The Florida data come from a variety of sources. The primary source for student-level information is the Florida Department of Education's K-20 Education Data Warehouse (K-20 EDW), an integrated longitudinal database covering all public school students and teachers in the state of Florida. The K-20 EDW includes detailed enrollment, demographic, and program participation information for each student, as well as their reading and math achievement test scores. As the name implies, the K-20 EDW includes student records for K-12 public school students and students enrolled in community colleges or four-year public universities in Florida. The K-20 EDW also contains information on the Florida Resident Assistance Grant (FRAG), a grant available to Florida residents who attend private colleges and universities in the state. Data from the National Student Clearinghouse (NSC), a national database that includes enrollment data from 3,300 colleges throughout the United States, is used to track college attendance outside the state of Florida, as well as any private college enrollment in Florida that the FRAG data do not pick up. Unfortunately, the Florida Department of Education's data-sharing agreement with the NSC expired in the latter part of the 2000s, so we can only reliably track 
students who attended private colleges and universities within Florida or any postsecondary institution outside of Florida through school year 2006-2007. ${ }^{3}$

The identity and location of schools is determined by the Master School ID files (for public K-12 schools) and the Non-Public Master Files (for private schools) maintained by the Florida Department of Education. Grade offerings are determined by enrollment in the October membership survey and by the school grade configuration information in the relevant school ID file.

We also collect information on employment outcomes from the Florida Education and Training Placement Information Program (FETPIP). FETPIP reports information for any individual who has participated in any public education or training program in Florida. The FETPIP data contain unemployment insurance (UI) records, which provide information on a person's quarterly earnings and the employer's North American Industry Classification System (NAICS) code. This allows us to determine the employment status and income of all Florida high school students who remain in the state and are employed in industries covered by UI. ${ }^{4}$ The Florida Department of Education routinely links these data to elements in the K-20 EDW and are assigned an individual-level anonymous student ID code.

High school graduation is determined by withdrawal information and student award data from the K-20 EDW. Only students who receive a standard high school diploma are considered to be high school graduates. Students earning a GED or special education diploma are counted as not graduating. Similarly, students who withdrew with no intention of returning or exited for other reasons (such as non-attendance, court action, joining the military, marriage, pregnancy, or

\footnotetext{
${ }^{3}$ Information on the NSC is available at www.studentclearinghouse.org.

${ }^{4}$ Excluded are members of the armed forces, the self-employed, proprietors, domestic workers, and railroad workers covered by the railroad unemployment insurance system. In addition, only about half of all workers in agricultural industries are covered.
} 
medical problems), but did not later graduate, are counted as not graduating. Students who died while in school are removed from the sample. It is not possible to directly determine the graduation status of students who leave the Florida public school system to attend a homeschooling program or to enroll in a private school, or who move out of state. Similarly, some students leave the public school system for unknown reasons. In the sample, students whose graduation status is unknown are more likely to have lower eighth-grade test scores and possess other characteristics associated with a reduced likelihood of graduation. They also are more likely to attend a traditional high school initially, rather than a charter high school. To avoid possible bias associated with differential sample attrition, we impute the graduation status for those students whose graduation outcome is unknown, based on predicted values from a regression model of graduation. ${ }^{5}$ Because we can track college attendance both within and outside of Florida, no imputation is necessary for the college attendance variable. Any individual who does not show up as enrolled in a two-year or four-year college or university is classified as a non-attendee.

The available data cover four cohorts of eighth-grade students in Florida. Statewide achievement testing for eighth-grade students began in school year 1997-1998, so the first cohort in the sample are students who attended eighth grade in $1997-1998 .{ }^{6}$ The last available year of K-12 and in-state college enrollment data is 2009-2010. Out-of-state postsecondary data are available only through the 2006-2007 school year, however. Employment data are available through calendar year 2011. Because we want to be able to determine employment outcomes

\footnotetext{
${ }^{5}$ Imputation was done with the uvis procedure in Stata. All variables reported in Table 3, except for the charter high school attendance variable, were used to predict graduation. If students whose graduation status is unknown are removed from the sample (rather than having their graduation status imputed), we obtain similar, though somewhat larger, estimated effects of charter attendance on high school graduation. If all students with an unknown graduation status are assumed to be dropouts, we obtain even larger estimated effects of charter high school attendance.

${ }^{6}$ Data on limited English proficiency (LEP) and special education program participation begin in 1998-1999, so they are not available for the first eighth-grade cohort. For these students, we use their LEP and special education status in ninth grade.
} 
after most students have completed their postsecondary education, the last cohort we include in the analysis are students who attended grade 8 in 2000-2001 (and began high school in 20012002).

\section{B. Chicago}

We obtained the Chicago data from the Chicago Public Schools Department of Postsecondary Education. The data include all students who attended charter schools in Chicago in eighth grade, whether they attended a charter high school or traditional public high school. The data cover six cohorts of eighth-grade students: students who began eighth grade from school years 1997-1998 through 2002-2003.

The data include student records for grades 8-12 from the Chicago Public Schools data system, with eighth-grade math and reading scaled scores on the Iowa Test of Basic Skills and information on student gender, race/ethnicity, bilingual status, free or reduced-price lunch status, and special education status. The data are also linked to the NSC, which tracks college attendance and persistence for students who graduated from public schools in Chicago.

High school graduation is determined by withdrawal information from the Chicago Public School data. Only students who receive a standard high school diploma are considered to be high school graduates. For students who leave the Chicago public school system, we impute graduation status with a regression model, as described for Florida. For Chicago, we only have college attendance data for students who graduated from Chicago public high schools, so we also impute college attendance for students with missing graduation data, using the same regression model as for graduation imputation. 


\section{Descriptive Data}

Table 1 provides an overview of the number of charter schools operating in Florida and Chicago, broken down by grade offerings and year. In Florida, the number of charters operating grew rapidly, nearly tripling over the four years that the sample cohorts would have entered ninth grade. Traditional grade groupings dominate among Florida charter schools: roughly two-thirds of charter schools offer only elementary, middle, or high school grades. As in Florida, the charter sector in Chicago experienced rapid growth: over the sample period, the number of charter schools expanded from 10 to 25 .

Table 1. Number of Charter Schools in Operation, by Grade Range and Year

\begin{tabular}{|l|c|c|c|c|c|c|c|c|c|}
\hline & \multicolumn{4}{|c|}{ Florida } & \multicolumn{5}{c|}{ Chicago } \\
\hline \multicolumn{1}{|c|}{ Grade Offerings } & $\begin{array}{c}1998- \\
1999\end{array}$ & $\begin{array}{c}1999- \\
2000\end{array}$ & $\begin{array}{c}2000- \\
2001\end{array}$ & $\begin{array}{c}2001- \\
2002\end{array}$ & $\begin{array}{c}1998- \\
1999\end{array}$ & $\begin{array}{c}1999- \\
2000\end{array}$ & $\begin{array}{c}2000 \\
2001\end{array}$ & $\begin{array}{c}2001- \\
2002\end{array}$ & $\begin{array}{c}2002- \\
2003\end{array}$ \\
\hline Elementary Only & 25 & 37 & 52 & 68 & 2 & 2 & 11 & 9 & 7 \\
\hline $\begin{array}{l}\text { Elementary, Middle, } \\
\text { and High School } \\
\text { Grades }\end{array}$ & 2 & 5 & 4 & 8 & 2 & 2 & 6 & 6 & 6 \\
\hline $\begin{array}{l}\text { Elementary and } \\
\text { Middle Grades }\end{array}$ & 15 & 21 & 35 & 40 & 1 & 2 & 7 & 9 & 11 \\
\hline $\begin{array}{l}\text { Middle Grades Only } \\
\text { Middle and Some } \\
\text { High School Grades }\end{array}$ & 2 & 4 & 1 & 3 & 1 & 0 & 0 & 0 & 0 \\
\hline $\begin{array}{l}\text { Middle and All High } \\
\text { School Grades }\end{array}$ & 6 & 5 & 6 & 7 & 1 & 2 & 0 & 0 & 0 \\
\hline $\begin{array}{l}\text { Only High School } \\
\text { Grades }\end{array}$ & 5 & 13 & 20 & 26 & 2 & 3 & 1 & 1 & 1 \\
\hline Total & $\mathbf{6 7}$ & $\mathbf{1 0 5}$ & $\mathbf{1 4 1}$ & $\mathbf{1 7 6}$ & $\mathbf{1 0}$ & $\mathbf{1 2}$ & $\mathbf{2 5}$ & $\mathbf{2 5}$ & $\mathbf{2 5}$ \\
\hline
\end{tabular}

Note: Number of charter schools and grade ranges based on student membership counts.

Table 2 provides summary statistics on student characteristics. For each jurisdiction, the students are distinguished by transition type: charter middle school to charter high school (the treatment group for the analysis) and charter middle school to traditional public 
Table 2. Baseline Descriptive Statistics of Treatment and Comparison Groups

\begin{tabular}{|c|c|c|c|c|c|c|c|c|}
\hline & \multicolumn{4}{|c|}{ Florida } & \multicolumn{4}{|c|}{ Chicago } \\
\hline & \multicolumn{2}{|c|}{$\begin{array}{c}\text { Charter in G8, } \\
\text { Charter in G9 } \\
\text { (Treatment } \\
\text { Group) }\end{array}$} & \multicolumn{2}{|c|}{$\begin{array}{l}\text { Charter in G8, } \\
\text { Traditional in G9 } \\
\text { (Comparison } \\
\text { Group) }\end{array}$} & \multicolumn{2}{|c|}{$\begin{array}{c}\text { Charter in G8, } \\
\text { Charter in G9 } \\
\text { (Treatment } \\
\text { Group) }\end{array}$} & \multicolumn{2}{|c|}{$\begin{array}{l}\text { Charter in G8, } \\
\text { Traditional in G9 } \\
\text { (Comparison } \\
\text { Group) }\end{array}$} \\
\hline & Obs & Mean & Obs & Mean & Obs & Mean & Obs & Mean \\
\hline Math Score, G8 (normed) & 1,293 & 0.078 & 2,831 & -0.231 & 471 & -0.186 & 517 & -0.093 \\
\hline Reading Score, G8 (normed) & 1,283 & 0.118 & 2,818 & -0.173 & 471 & -0.195 & 515 & -0.108 \\
\hline Female & 1,304 & 0.486 & 2,914 & 0.467 & 474 & 0.563 & 523 & 0.530 \\
\hline Black & 1,295 & 0.178 & 2,893 & 0.370 & 474 & 0.835 & 523 & 0.834 \\
\hline Hispanic & 1,295 & 0.189 & 2,893 & 0.106 & 474 & 0.143 & 523 & 0.132 \\
\hline Asian & 1,295 & 0.017 & 2,893 & 0.010 & 474 & 0.000 & 523 & 0.002 \\
\hline LEP/Bilingual in G8 & 1,304 & 0.023 & 2,914 & 0.009 & 474 & 0.093 & 523 & 0.082 \\
\hline Special Ed in G8 & 1,304 & 0.103 & 2,914 & 0.152 & 474 & 0.108 & 523 & 0.134 \\
\hline Free/R-P Lunch in G8 & 1,304 & 0.225 & 2,914 & 0.411 & 395 & 0.896 & 463 & 0.896 \\
\hline Change Schools in G7-8 & 1,175 & 0.716 & 2,663 & 0.674 & 474 & 0.272 & 523 & 0.264 \\
\hline 1997 G8 Cohort & 1,304 & 0.001 & 2,914 & 0.027 & & & & \\
\hline 1998 G8 Cohort & 1,304 & 0.102 & 2,914 & 0.115 & 474 & 0.114 & 523 & 0.061 \\
\hline 1999 G8 Cohort & 1,304 & 0.336 & 2,914 & 0.382 & 474 & 0.190 & 523 & 0.153 \\
\hline 2000 G8 Cohort & 1,304 & 0.561 & 2,914 & 0.476 & 474 & 0.177 & 523 & 0.203 \\
\hline 2001 G8 Cohort & & & & & 474 & 0.306 & 523 & 0.231 \\
\hline 2002 G8 Cohort & & & & & 474 & 0.213 & 523 & 0.352 \\
\hline $\begin{array}{l}\text { Proportion of G9 Schoolmates Who } \\
\text { Were Schoolmates in G8 }\end{array}$ & 1,303 & 0.603 & 2912 & 0.041 & 474 & 0.153 & 523 & 0.032 \\
\hline
\end{tabular}

high school (the comparison group). ${ }^{7}$ The raw data indicate that the Chicago treatment (charter eighth grade to charter ninth grade) and comparison (charter eighth grade to traditional ninth grade) groups were remarkably similar in eighth grade in nearly every descriptive characteristic, but the Florida treatment and comparison groups differed on more dimensions. In Chicago, the treatment and comparison groups were nearly indistinguishable in eighth grade in race/ethnicity, poverty, limited English proficiency, and prior school mobility. The comparison group had slightly higher eighth-grade test scores and a slightly lower probability of having special

\footnotetext{
${ }^{7}$ Throughout the analysis, exposure to a charter high school is defined by the type of school a student attends in grade 9, whether or not the student subsequently stays in that type of school. This is done to avoid selection bias problems associated with transfer out of treatment; therefore, the estimates of charter school effects should be interpreted as analogous to "intent to treat" impact estimates. Significant numbers of students switch school types (primarily from charters back to traditional public schools) after ninth grade. Excluding these students has little effect on the results, however.
} 
education services. In Florida, the treatment group who went on to attend charter high schools had higher baseline test scores; were less likely to be black, low-income, and in need of special education services; and were more likely to be Hispanic, relative to the comparison group.

\section{Results}

\section{A. Implementation of Analytic Approach}

We first replicate our previous analysis of high school graduation and college enrollment (Booker et al., 2011) with an expanded sample that includes additional years of data. We measure high school graduation as receiving a standard high school diploma within five years of entering ninth grade. College enrollment is determined by enrollment in any postsecondary institution within six years of starting high school.

We extend the analysis in this paper by considering the long-run effects of charter high school attendance on persistence in college and earnings. We gauge persistence by assessing whether a student is enrolled in any postsecondary institution at least two consecutive years. The two-year persistence measure is important, because it typically takes at least two years to obtain a degree from a community college. In addition, dropout from four-year higher education institutions is highest in the first year, meaning persistence into the second year is correlated with degree completion in four-year institutions as well (Berkner \& Choy, 2008). Measuring persistence over a longer period would be desirable, but data limitations prevent us from conducting useful analyses of longer-term persistence and degree completion. In Florida, the available NSC data on college enrollment ends in 2006-2007, so we could only track our first cohort of students (who entered high school in 1998) through four years of college, and then only if they graduated high school within four years and entered college immediately. The data 
received from Chicago are likewise constrained, and they do not include indicators of postsecondary degree completion.

In Florida, we possess earnings data through the end of calendar year 2011. We can determine annual income for four student cohorts in the 10th and 11th years after beginning grade 8 and for three of the four cohorts 12 years after entering grade 8 . For example, employment of our last cohort of eighth graders (those attending grade 8 in 2000-2001) is measured through calendar year 2011. A student in that cohort who took four years to finish high school and four years to finish college would graduate from college in spring 2009, which would be nine years after the beginning of grade 8 . The following year (10 years after entering grade 8 ) represents the first full year of earnings after potentially graduating college. To account for initial employment in temporary jobs, early spells of unemployment, or employment in occupations outside one's long-term profession, we also measure the maximum annual earnings 10, 11, or 12 years from initial enrollment in grade 8. This latter measure is potentially the most reliable, because it maximizes our sample size and accounts for many of the short-term fluctuations in employment and earnings that can frequently occur among young job market entrants.

\section{B. Estimates of Attainment Impact}

Table 3 presents the estimated impacts of charter high schools on students' subsequent academic attainment, as measured by high school graduation, college entry, and college persistence. Estimated marginal probabilities (evaluated at the sample means) from probit equations, along with standard errors clustered at the school level, are reported. The estimated models include controls for student demographics, English-language skills, special education program participation, family income (proxied by free/reduced-price lunch status), and mobility 
during middle school. ${ }^{8}$ Student ability and prior educational inputs are accounted for by inclusion of eighth-grade test scores in math and reading. ${ }^{9}$

Table 3. Probit Estimates of the Effect of Attending a Charter High School on Educational Attainment (Coefficient Estimates Are Marginal Effects)

\begin{tabular}{|l|c|c|}
\hline & Florida & Chicago \\
\hline \multicolumn{2}{|c|}{ High School Completion } \\
\hline Receive Standard High School & $0.109^{* *}$ & $0.074^{*}$ \\
Diploma Within 5 Years/5+ Years & {$[0.027)$} & $(0.035)$ \\
& {$[\mathrm{N}=3,646]$} & {$[\mathrm{N}=997]$} \\
\hline \multicolumn{2}{|c|}{ College Attendance } \\
\hline Attend a Two-Year or Four-Year & $0.099^{* *}$ & $0.109^{* *}$ \\
College Within 6 Years & $(0.030)$ & $(0.042)$ \\
& {$[\mathrm{N}=3,649]$} & {$[\mathrm{N}=997]$} \\
\hline \multicolumn{2}{|c|}{ College Persistence } \\
Persist in Any College at Least Two & $0.126^{* *}$ & 0.066 \\
Consecutive Years & $(0.045)$ & $(0.046)$ \\
& {$[\mathrm{N}=3,376]$} & {$[\mathrm{N}=997]$} \\
\hline
\end{tabular}

Note: Standard errors adjusted for clustering at the school level are in parentheses. + significant at $10 \%$; significant at 5\%; ** significant at 1\%. Each model includes controls for student demographics, English-language skills, special education program participation, family income (proxied by free/reduced-price lunch status), mobility during middle school, eighth-grade test scores in math and reading, and a set of cohort indicators.

The first panel of Table 3 presents estimates of the impact of charter high school attendance on the probability of earning a standard high school diploma within five years. Similar to the results reported in Booker et al. (2011), we find that charter high school enrollment is associated with a 7 to 11 percentage point increase in the probability of earning a standard high school diploma within five years. ${ }^{10}$

\footnotetext{
${ }^{8}$ In Florida, English-language skills are measured by participation in an LEP program. In Chicago, Englishlanguage skills are measured by participation in a bilingual program. Student mobility is measured by an indicator for students who changed schools between grades 6 and 7 or between grades 7 and 8 .

${ }^{9}$ In Florida, we use the student's scale scores on the FCAT-SSS test, a criterion-referenced test based on the state's curriculum standards. The Stanford Achievement Test is also administered to students in Florida, but administration of the Stanford test did not begin until school year 1999-2000. In Chicago, we use the student's scale score on the Iowa Test of Basic Skills, a criterion-referenced test used in Illinois during this period.

${ }^{10}$ The results reported here differ slightly from those in Booker et al. (2011), where we estimated the impact of charter high schools on diploma receipt to be seven to 15 percent. The key difference is that we now have more
} 
In both Chicago and Florida, estimates of the effects of attending charter high schools on the probability of enrolling in college are positive, statistically significant, and quantitatively substantial, as indicated in the second panel of Table 3. Using a six-year window from the beginning of high school, we find that charter high school enrollment in Florida leads to a 10 percentage point increase in the probability of attending college; for Chicago, the estimated impact is 11 percentage points. ${ }^{11}$

The third panel shows results for an outcome that we could not examine in the preceding paper: persistence in college. We define persistence as attending college at least one semester in consecutive academic years following initial college entry. In both locations, the estimated impacts on college persistence are positive, but only the Florida results achieve statistical significance. Point estimates for two-year persistence suggest a 13 percentage point advantage for charter high school students in Florida and a 7 percentage point (nonsignificant) advantage for charter high schools in Chicago.

The net long-term effect on persisting in college consists of some combination of the effect on the likelihood of graduating high school, the effect on enrolling in college for those who graduate from high school, and the effect of persisting in college for those who enroll in college. It would be interesting to know the extent to which charter high schools affect the persistence of the subset of students who enter college. There is no straightforward way to produce an unbiased estimate of the effect on college persistence conditional on college entry, however, because the treatment (charter high school enrollment) affects the likelihood of entering college. The methodological problem is analogous to a problem often seen in studies of

years of data, so we can include an additional cohort in the estimation of diploma receipt and college attendance within five years of attending grade 8 for Florida.

${ }^{11}$ In our previous work, Booker et al. (2011), we employed a five-year window for college enrollment. With the additional data acquired since our previous paper, we extend the window for college entry to six years after high school entry, thereby providing an opportunity for late-graduating high school students to enter college. 
wage impacts when the treatment affects labor force participation as well as wages (see, for example, Lee 2009; Heckman 1979). In other words, by increasing the number of students attending college, the charter high school treatment changes the sample of students in a conditional analysis of effects on those attending college, creating a sample bias relative to the comparison group.

We can modify the probit analysis that was used to produce the unconditional impact estimates in Table 3 by constraining the sample to include only those students who attended college, but the resulting conditional impact estimates will be biased by the sample change produced by the effect on college entry. Given that the treatment has increased the number of students entering college - presumably adding students who had lower ability levels in eighth grade and perhaps less motivation for college - the conditional impact estimate is likely to be biased downward.

Table 4 shows the results of the conditional impact analysis. ${ }^{12}$ In Florida, charter school graduates are significantly more likely to persist for two years, even after controlling for

\footnotetext{
12 The effect of charter high school enrollment on college persistence, conditional on college attendance, equals the probability of persistence for charter students conditional on going to college less the probability of persistence for traditional high school students conditional on going to college; this is the estimate reported in Table 4. The difference in persistence conditional on college attendance cannot be derived simply by comparing the estimated unconditional effects of charter attendance on college attendance and college persistence from Table 3 . The coefficients reported in the second and third panels of Table 3 are not the probabilities of college attendance and college persistence for a given group (charter or traditional high school attendees); rather, they represent the difference in the probabilities between the two groups. Thus, the coefficient on charter high school attendance in the college attendance equation represents the difference in the probability of going to college for charter and traditional high school students. Similarly, the reported coefficient from the unconditional persistence equation is the difference in the unconditional probabilities of persistence in college between charter and traditional high school students. The difference between these two estimates equals:

$\left[\mathrm{P}(\text { college attendance })_{\text {charter }} \times \mathrm{P}(\text { persistence conditional on college attendance })_{\text {charter }}-\right.$
$\left.\mathrm{P}(\text { college attendance })_{\text {traditional }} \times \mathrm{P}(\text { persistence conditional on college attendance })_{\text {traditional }}\right]-$
$\left[\mathrm{P}(\text { college attendance })_{\text {charter }} \mathrm{P}(\text { college attendance })_{\text {traditional }}\right]$
$=\mathrm{P}(\text { college attendance })_{\text {charter }} \times\left[\mathrm{P}(\text { persistence conditional on college attendance })_{\text {charter }}-1\right]-$
$\mathrm{P}(\text { college attendance })_{\text {traditional }} \times\left[\mathrm{P}(\text { persistence conditional on college attendance })_{\text {traditional }}-1\right]$
}

Thus, the difference between the two estimates does not equal the difference in the conditional probabilities of persistence. 
postsecondary enrollment. In Chicago, the estimate of the effect on persisting in college conditional on enrolling is positive but insignificant and near zero. The results suggest that Florida charter high schools are not only increasing college entry but also increasing the persistence of those who enter. Conditional results for Chicago charter high schools are ambiguous; however, they suggest, at a minimum, that charter high school students are no less prepared to persist in college than they would have been if they had attended conventional (noncharter) high schools.

Table 4. Probit Estimates of Persisting in College for Two Years, Conditional on Initial Enrollment in College (Coefficient Estimates Are Marginal Effects)

\begin{tabular}{|l|c|c|}
\hline & Florida & Chicago \\
\hline Persist in Any College at Least Two & $0.085^{* *}$ & 0.023 \\
Consecutive Years & $(0.039)$ & $(0.039)$ \\
& {$[\mathrm{N}=1,821]$} & {$[\mathrm{N}=429]$} \\
\hline
\end{tabular}

Note: Standard errors adjusted for clustering at the school level are in parentheses. + significant at $10 \%$; significant at 5\%;* significant at $1 \%$. Model includes controls for student demographics, English-language skills, special education program participation, family income (proxied by free/reduced-price lunch status), mobility during middle school, eighth-grade test scores in math and reading, and a set of cohort indicators.

The estimates in Tables 3 and 4 indicate the impacts of charter high school attendance on the probabilities of graduating, enrolling in college, and persisting in college. Another way of gauging the effects of charter attendance on attainment is to determine the proportional increase in the numbers of students graduating, enrolling in college, and persisting in college as a result of having attended charter high schools. One can decompose the differences in attainment between charter and traditional high school attendees in a manner similar to the decomposition of wage differentials. Because college attendance and persistence are binary outcomes, we employ the variation of the Blinder/Oaxaca decomposition developed by Fairlie (2005). In particular, we can separately estimate the probabilities of college attendance and persistence for the subsamples of 
charter and traditional high school attendees and determine how much of the difference is due to differences in student characteristics. We can then estimate what proportion of the charter students would have graduated, enrolled in college, and persisted in college if they had the same observable characteristics as the average student who enrolled in a traditional high school. Using this procedure, Table 5 indicates the percentage increases in high school graduation, college enrollment, and college persistence produced by charter high schools in Chicago and Florida.

\section{Table 5. Estimated Rates of High School Graduation, College Attendance, and College Persistence Based on Results from Probit Regressions}

\begin{tabular}{|c|c|c|c|c|c|c|}
\hline & \multicolumn{3}{|c|}{ Florida } & \multicolumn{3}{|c|}{ Chicago } \\
\hline & $\begin{array}{c}\text { Charter in G8, } \\
\text { Charter in G9 } \\
\text { (if Mean } \\
\text { Student } \\
\text { Characteristics } \\
\text { Same as } \\
\text { Charter-in-G8/ } \\
\text { Traditional-in- } \\
\text { G9 Group) }\end{array}$ & $\begin{array}{c}\text { Charter in G8, } \\
\text { Traditional in } \\
\text { G9 } \\
\text { (Actual Mean } \\
\text { Student } \\
\text { Characteristics) }\end{array}$ & $\begin{array}{c}\text { Relative } \\
\text { Increase } \\
\text { (in } \\
\text { percentage) }\end{array}$ & $\begin{array}{c}\text { Charter in G8, } \\
\text { Charter in G9 } \\
\text { (if Mean } \\
\text { Student } \\
\text { Characteristics } \\
\text { Same as } \\
\text { Charter-in-G8/ } \\
\text { Traditional-in- } \\
\text { G9 Group) }\end{array}$ & $\begin{array}{c}\text { Charter in G8, } \\
\text { Traditional in } \\
\text { G9 } \\
\text { (Actual Mean } \\
\text { Student } \\
\text { Characteristics) }\end{array}$ & $\begin{array}{c}\text { Relative } \\
\text { Increase } \\
\text { (in } \\
\text { percentage) }\end{array}$ \\
\hline $\begin{array}{l}\text { Percentage } \\
\text { Receiving } \\
\text { Standard High } \\
\text { School } \\
\text { Diploma } \\
\text { Within 5/5+ } \\
\text { Years }\end{array}$ & 68.89 & 60.80 & 13.31 & 73.92 & 67.80 & 9.03 \\
\hline $\begin{array}{l}\text { Probability } \\
\text { Attend a Two- } \\
\text { Year or Four- } \\
\text { Year College } \\
\text { Within } 6 \text { Years }\end{array}$ & 58.80 & 50.36 & 16.76 & 51.91 & 47.48 & 9.33 \\
\hline $\begin{array}{l}\text { Persist in Any } \\
\text { College at } \\
\text { Least Two } \\
\text { Consecutive } \\
\text { Years }\end{array}$ & 43.26 & 31.86 & 35.78 & 44.19 & 38.74 & 14.07 \\
\hline
\end{tabular}

In Florida, the charter high school students show a consistent advantage in absolute terms of 8 to 11 percentage points from high school graduation through a second year of college enrollment. In relative terms, however, the proportional increase in attainment for charter high 
school students increases at each level: charter high schools in Florida appear to produce a 13 percent relative increase in high school graduates, a 17 percent increase in college entrants, and a 36 percent relative increase in students who persist at least two years in college, compared to the numbers who would have reached these thresholds if they had attended conventional public high schools.

In Chicago, the attainment difference is higher for college entry than persistence in absolute terms, but they are similar in proportional terms. Charter high schools in Chicago show a 9 percent relative increase in high school graduates and college entrants, and a 14 percent relative increase in students who persist at least two years in college.

\section{Impacts on Earnings}

In Florida, we can also examine whether students who attend charter high schools have higher subsequent earnings than observationally equivalent students who attend traditional public schools (again restricting the analysis so that treatment group and comparison group were enrolled in charter schools in eighth grade). We measure the labor outcome as income up to 12 years after the student's start of the eighth-grade year, unconditionally of whether the student attended college. Assuming a normal progression of four years to graduate from high school and four years of college, we would be measuring earnings in the calendar year up to three years after college graduation. Assuming kindergarten entry at age 5 and no grade repeating in elementary or middle school, students would be up to age $25 .{ }^{13}$

Table 6 displays OLS estimates of the earnings equation with the restricted sample. Not surprisingly, estimates for the 10-year window are generally smaller and less precise than for the 11- and 12-year windows. As noted earlier, students who took time off between high school and

\footnotetext{
${ }^{13}$ To account for part-time or temporary work, we conducted sensitivity analyses in which we restricted the sample to individuals earning at least $\$ 1,000$ for the year or at least $\$ 1,000$ in each quarter. Imposing these sample restrictions did not substantively change our conclusions.
} 
college or took more than four years to complete college could still be in school or just recently graduated 10 years after the start of eighth grade. Even for those who have completed their formal education, they still may not be settled into their careers. Again, assuming kindergarten entry at age 5 and normal progression, the 10 -year window would be measuring labor market outcomes at age 23 . Therefore, although the overall estimates for the 10-year window are positive, they are the least precise, and we do not place much weight on these results.

Table 6. OLS Estimates of the Effect of Florida Charter High School Attendance on Annual Earnings, by Cohort and by Years Since Beginning Grade 8

\begin{tabular}{|c|c|c|c|c|}
\hline \multicolumn{5}{|c|}{ Years Since Beginning Grade 8} \\
\hline Cohort & 10 Years & 11 Years & 12 Years & $\begin{array}{c}\text { Max. of 10, } \\
11 \text {, and } 12 \\
\text { Years } \\
\end{array}$ \\
\hline $\begin{array}{l}\text { G8 in } 1997 \\
\text { and G8 in } \\
1998\end{array}$ & $\begin{array}{c}2,373.56 \\
(1,884.86) \\
{[\mathrm{N}=272]}\end{array}$ & $\begin{array}{c}4,217.10^{+} \\
(2,249.56) \\
{[\mathrm{N}=254]}\end{array}$ & $\begin{array}{c}4,214.37 \\
(3,094.27) \\
{[\mathrm{N}=248]}\end{array}$ & $\begin{array}{c}3,729.28 \\
(2,833.53) \\
{[N=324]}\end{array}$ \\
\hline G8 in 1999 & $\begin{array}{c}2,940.46^{* *} \\
(805.35) \\
{[\mathrm{N}=728]}\end{array}$ & $\begin{array}{c}3,605.50^{* *} \\
(1,007.11) \\
{[\mathrm{N}=717]}\end{array}$ & $\begin{array}{c}4,211.69^{* *} \\
(1,380.57) \\
{[\mathrm{N}=713]}\end{array}$ & $\begin{array}{c}4,443.76^{* *} \\
(1,222.95) \\
{[N=897]}\end{array}$ \\
\hline G8 in 2000 & $\begin{array}{c}-361.54 \\
(1,027.75) \\
{[N=1,053]}\end{array}$ & $\begin{array}{l}763.85 \\
(1,164.93) \\
{[N=1,059]}\end{array}$ & & $\begin{array}{c}526.06 \\
(1,147.17) \\
{[N=1,227]}\end{array}$ \\
\hline All & $\begin{array}{c}1,142.91 \\
(851.42) \\
{[N=2,053]}\end{array}$ & $\begin{array}{c}2,201.66^{*} \\
(904.26) \\
{[\mathrm{N}=2,030]}\end{array}$ & $\begin{array}{c}4,420.88^{* *} \\
(1,159.70) \\
{[\mathrm{N}=961]}\end{array}$ & $\begin{array}{l}2,346.55^{*} \\
(1,030.92) \\
{[\mathrm{N}=2,448]}\end{array}$ \\
\hline
\end{tabular}

Note: Standard errors adjusted for clustering at the school level are in parentheses. + significant at $10 \%$; * significant at $5 \% ; * *$ significant at $1 \%$. Sample size in brackets.

Results based on 11- and 12-year post-grade-8 windows likely provide a better picture of the long-run earnings of former students. The effects of charter high school attendance are quantitatively substantial and statistically significant. The 11-year results yield an estimated increase in annual earnings of $\$ 2,200$. Although the 12-year window provides the longest time 
for students to complete their education and settle into the workforce, we lose one cohort of students, and the sample size is cut in half. Despite this, we find the impact of charter high school attendance on earnings 12 years from eighth-grade entry to be positive, large in magnitude, and statistically significant. Seeking a balance between sample size and earnings stability, we also estimated the impact of charter high school attendance on the maximum earnings obtained in the 10-, 11-, or 12-year windows. Using this approach, we have a sample size of nearly 2,500 students, and the OLS regression yields an estimated charter high school effect on annual earnings of $\$ 2,347$. Given average maximum earnings over the 10-, 11-, and 12year windows are equal to $\$ 22,577$ for all students and $\$ 20,001$ for former charter middle school students, the estimated impacts are large, showing a 12.7 percent increase in the maximum earnings achieved over the three-year span. The estimated impact on earnings is relatively large and despite the steps we take to control for differences between charter high school and noncharter high school students, we cannot entirely rule out the possibility that there exists some upward bias due to selection. However, the degree of bias would have to be extremely large to completely negate the positive estimated impact of charter high school attendance. For example, the bias due to unobservables would have to be one and one-half times the estimated black-white earnings differential of $\$ 1557$.

We also estimated the impact of charter high school attendance on earnings separately for each cohort. Interestingly, the estimates are much larger and more precise for the year 1999 eighth-grade cohort than for the other three cohorts. It is not clear why this is so. To the extent that the stronger results for the 1999 cohort are driven by year-specific labor market characteristics, these are taken into account in the across-cohort estimates by including a set of cohort indicators. 
To determine whether the earnings effect of charter high school attendance is due solely to increased postsecondary attainment, we reestimate the earnings equation separately for the subsamples of students who did and did not attend a two-year or four-year college within six years of grade 8 . Table 7 presents the results. The 10 -year window is problematic because many college attendees probably have not finished their education. Focusing on the 11-year, 12-year, and max-earnings results, we find positive effects for both the non-college attendees and the college attendees, although the effects for the non-college attendees are not statistically significant. For college attendees, the estimated charter coefficient is positive and significant, suggesting that, even among students who went to college, charter students have an earnings advantage. Therefore, college attendance alone cannot explain the advantage of the earning difference we see for the full sample. It is possible that the charter schools are developing skills for students that enhance the students' value in the labor market, whether or not they attend college. These could include noncognitive skills (such as a strong work ethic) or cognitive skills (such as analytic ability and problem solving).

Table 7. OLS Estimates of the Effect of Florida Charter High School Attendance on Annual Earnings, by Years Since Beginning Grade 8 and by College Attendance

\begin{tabular}{|l|c|c|c|c|}
\hline \multicolumn{5}{|c|}{ Years Since Beginning Grade 8 } \\
\hline \multicolumn{1}{|c|}{ Sample } & 10 Years & 11 Years & 12 Years & $\begin{array}{c}\text { Max. of 10, } \\
11, \text { and 12 } \\
\text { Years }\end{array}$ \\
\hline All & $\begin{array}{c}1,142.91 \\
(851.42) \\
{[\mathrm{N}=2053]}\end{array}$ & $\begin{array}{c}2,201.66^{*} \\
(904.26) \\
{[\mathrm{N}=2,030]}\end{array}$ & $\begin{array}{c}4,420.88^{* *} \\
(1,159.70) \\
{[\mathrm{N}=961]}\end{array}$ & $\begin{array}{c}2,346.55^{*} \\
(1,030.92) \\
{[\mathrm{N}=2,448]}\end{array}$ \\
\hline $\begin{array}{l}\text { No College } \\
\text { with 6 Years }\end{array}$ & $\begin{array}{c}2,211.90 \\
(1,723.27) \\
{[\mathrm{N}=782]}\end{array}$ & $\begin{array}{c}2,065.82 \\
(1,542.94) \\
{[\mathrm{N}=788]}\end{array}$ & $\begin{array}{c}3,805.60 \\
(2,698.43) \\
{[\mathrm{N}=413]}\end{array}$ & $\begin{array}{c}2,164.82 \\
(1,856.85) \\
{[\mathrm{N}=967]}\end{array}$ \\
\hline
\end{tabular}




\begin{tabular}{|c|c|c|c|c|}
\hline $\begin{array}{l}\text { Attend } \\
\text { College within } \\
6 \text { Years }\end{array}$ & $\begin{array}{c}852.49 \\
(950.58) \\
{[1,271]}\end{array}$ & $\begin{array}{c}2,164.84^{* *} \\
(908.28) \\
{[1,242]}\end{array}$ & $\begin{array}{c}4,390.50 * * * \\
(1,025.93) \\
{[\mathrm{N}=548]}\end{array}$ & $\begin{array}{l}2,408.10^{* *} \\
(1,074.47) \\
{[\mathrm{N}=1,481]}\end{array}$ \\
\hline
\end{tabular}

Note: Standard errors adjusted for clustering at the school level are in parentheses. + significant at $10 \%$; significant at $5 \% ; * *$ significant at $1 \%$. Sample size in brackets.

\section{Conclusion}

In previous work, we produced the first evidence of the effects of charter schools on the probability of graduating from high school and entering college (Booker et al., 2011). Enough time has now passed that the same cohorts of students in Chicago and Florida have had the opportunity to enroll in college for multiple years and to begin careers. In this paper, we used the same approach as in our previous work — relying on a restricted sample of students who were all (treatment and comparison group alike) enrolled in charter school in eighth grade - to estimate the effect of charter high schools on persistence in college and earnings.

We continue to find that charter high schools in both locations increase the probability that a student will graduate and enter college. In addition, our new set of results suggests that students from charter high schools are more likely to persist in college for at least two years. The college persistence findings are not as clear-cut as the findings on high school graduation and college entry, because the estimated impact is statistically significant in only one of the two sites (Florida). Estimates in both sites are positive and nontrivial in magnitude, however, consistent with the interpretation that the attainment effect of charter schools goes beyond merely helping their students to enroll in college.

In Florida, we also examine data on the subsequent earnings of students in our analytic sample, at a point after they could have earned college degrees. Charter high school attendance is associated with an increase in maximum annual earnings for students between ages 23 and 25 of 
$\$ 2,347$ - or about 12.7 percent higher earnings than for comparable students who attended a charter middle school but matriculated to a traditional high school.

The substantial positive impacts of charter high schools on attainment and earnings are especially striking, given that charter schools in the same jurisdictions have not been shown to have large positive impacts on students' test scores (Sass, 2006; Zimmer et al., 2012). Exactly what charter high schools are doing to produce substantial positive effects on educational attainment and earnings is an open question. Charter high schools might be able to produce positive effects on initial college entry merely by providing better counseling and encouragement to apply and enroll. But that could not explain higher rates of persistence in college or higher earnings, suggesting that charter high schools are endowing their students with skills that are useful for success in college and career but that test scores do not capture. The fact that charter high school students have higher earnings even if they do not attend college further supports this interpretation. To more fully understand what is causing the improved educational attainment and labor outcomes, research is needed on the practices and operations of charter high schools relative to traditional public high schools. To assess the generalizability of our findings, additional research on long-term charter effects in other locations would also be useful.

Positive impacts on long-term attainment outcomes and earnings are, of course, more consequential than outcomes on test scores in school. It is possible that charter schools' full longterm impacts on their students have been underestimated by studies that examine only test scores. More broadly, the findings suggest that the research examining the efficacy of educational programs should examine a broader array of outcomes than just student achievement.

\section{Appendix A. Determinants of Charter High School Attendance}


For the results presented in the main text, we employ two strategies to mitigate potential bias from self-selection into charter high schools. First, we restrict our sample to students who attended a charter middle school, thus indirectly accounting for many of the unobserved factors that determine school choice. Second, we control for a wide range of observable factors, including mobility in middle school, eighth-grade test scores, and student/family demographic characteristics. The possibility still exists, however, that unmeasured factors could be affecting both the choice of high school and student outcomes, which would lead to biased estimates of the impact of charter high school attendance. To test whether this is occurring and to provide further safeguards against possible selection bias, we estimate a high school selection equation. The selection equation is then employed in a bivariate probit (for the dichotomous outcomes) or IV (for the continuous outcome) procedure.

\section{A. Determinants of High School Choice}

Whether one attends a charter school could be a function of parental/student preferences, as well proximity to school alternatives, including charter, private, and traditional public schools (Butler, Carr, Toma, \& Zimmer, 2013). Most private schools predate charters in our sample, and competition from private schools likely had an impact on the operation of traditional public schools even before charters came on the scene. Similarly, charter school entrants would likely take into account the availability and characteristics of nearby private schools when designing their schools. In a simple product variety model of competition, private schools would initially offer a mix of attributes that differs significantly from that of traditional public schools. If charters enter an environment with significant private-school penetration, they would tend to locate "closer" to traditional public schools in product attribute space than if no private-school 
competitors existed. ${ }^{14}$ Therefore, we would expect that, in areas where there is vibrant competition from private high schools, students would be less likely to choose a charter high school over a traditional high school because the charters would be more similar to the traditional public schools. $^{15}$

We measure the physical proximity of other charter high schools by the minimum linear distance from a student's eighth-grade charter to a different charter school offering grade 9 and by the number of other charter high schools within various radii. Similarly, in Florida, we capture the time cost of a attending a traditional public school by the distance to the nearest traditional public high school. As in recent work by Barrow, Claessens, and Schanzenbach (2009) on "small schools" in Chicago, we do not include a measure of traditional high school proximity, because there is not much variation in the distance to the nearest traditional high school within the city of Chicago. Because traditional public school students usually are assigned based on residential location, we do not include a count of the number of nearby traditional public high schools in either Florida or Chicago. One factor that would affect whether a student attends a charter school for high school is whether the middle school the student is currently attending offers high school grades, including grade 9 . In this case, the distance would be zero.

In Table A.1, we present probit estimates of the choice of attending a charter school in grade 9 as a function of both the grade offerings of a student's middle school and the availability

\footnotetext{
${ }^{14}$ Glomm, Harris, and Lo (2005) also use a product differentiation approach and similar reasoning to empirically analyze the location decisions of charter schools.

${ }^{15}$ Locating between traditional public schools and private schools in product attribute space, charters would also expect to draw away families who would otherwise go to private schools. Indeed, depending on the size of the private sector and the distribution of consumer preferences, charters may choose to adopt attributes similar to those of private schools. We would, however, expect charters to be at least somewhat more similar to traditional public schools than are private schools to traditional public schools. If traditional public schools responded to preexisting private school competition by making their product "closer" to the offerings of private schools, there would be less "distance" between traditional public schools and private schools, which would also reduce the expected enrollment in charter schools.
} 
of other school alternatives. Separate results are presented for various radii from the student's middle school location. We measure the grade configurations of charter schools by an indicator

Table A.1. Probit Estimates of Attending a Charter High School in Grade 9, Based on Minimum Distance and Number of Schools of Given Type in Surrounding Area Offering Grade 9 in Relevant Year (Coefficient Estimates Are Marginal Effects)

\begin{tabular}{lccccc} 
& \multicolumn{5}{c}{ Florida } \\
& $10 \mathrm{mi}$. & $5 \mathrm{mi}$. & $2.5 \mathrm{mi}$. & $5 \mathrm{mi}$. & $2.5 \mathrm{mi}$. \\
& & & & & \\
Distance to Nearest & 0.0439 & 0.0041 & 0.0360 & & \\
Traditional Public School & $(0.0315)$ & $(0.0206)$ & $(0.0258)$ & & \\
Distance to Nearest & -0.0026 & -0.0029 & -0.0048 & 0.0149 & 0.1063 \\
Other Charter & $(0.0048)$ & $(0.0037)$ & $(0.0046)$ & $(0.0444)$ & $(0.0840)$ \\
Eighth-Grade Charter Offers & $0.4440^{* *}$ & $0.3126^{*}$ & $0.4900^{* *}$ & $0.5426^{* *}$ & 0.1125 \\
Grade 9 & $(0.1412)$ & $(0.1589)$ & $(0.1320)$ & $(0.1147)$ & $(0.3023)$ \\
Number of Other Charters & 0.0468 & 0.0490 & 0.0092 & 0.0907 & $0.7832^{* *}$ \\
& $(0.0364)$ & $(0.0479)$ & $(0.0595)$ & $(0.0687)$ & $(0.3022)$ \\
Number of Private Schools & -0.0014 & $-0.0395^{*}$ & -0.0405 & -0.0180 & -0.0739 \\
& $(0.0050)$ & $(0.0218)$ & $(0.0493)$ & $(0.0146)$ & $(0.0545)$ \\
Observations & & & & & \\
Pseudo R-squared & 4216 & 4216 & 4216 & 996 & 996 \\
& 0.22 & 0.27 & 0.21 & 0.24 & 0.23
\end{tabular}

Note: Standard errors adjusted for clustering at the school level are in parentheses.

+ significant at $10 \% ; *$ significant at $5 \% ; * *$ significant at $1 \%$.

for whether or not a student's grade 8 charter school offered grade 9 in the year after the student attended eighth grade. As one would expect, the availability of ninth grade in the same school a student attended in eighth grade generally has a large positive impact on the likelihood of attending a charter school in grade 9. Except for the 2.5-mile radius in Chicago, the availability of ninth grade in the same school raises the probability of attending a charter high school from 31 to 49 percentage points, depending on the jurisdiction and the size of the geographic area under consideration. Holding constant the number of charter schools within a given area, an 
increase in the distance to the nearest charter high school decreases the likelihood of attending a charter high school in Florida, as one would expect, although the estimates are imprecise and never statistically significant. Similarly, as expected, increases in the distance to the nearest traditional public high school are positively correlated with the likelihood of attending a charter school in grade 9, although (once again) the effects are not statistically significant. Consistent with competition on product variety, the number of private schools is negatively correlated with the probability of attending a charter school in ninth grade, although the effect is statistically significant only for the five-mile radius in Florida.

The possibility exists that the determinants of high school choice also affect the outcome of interest (educational attainment or earnings). For example, if combining middle and high school grades improves student learning or fosters greater school attachment, then schools that offer both grades 8 and 9 may have positive effects on both the likelihood of attending a charter school in grade 9 and the probability of graduating from high school. In Table A.2, we present Wald tests of exclusion restrictions in the attainment and earnings equations for combinations of the explanatory variables used in the high school choice equation. ${ }^{16}$ For Florida, the number of charter schools and the number of private schools within five miles can be excluded from the graduation equation, and those two variables, plus the indicator for schools offering grade 9 , can be excluded from the college attendance equation. All the determinants of charter high school choice can be excluded from the earnings equation. For Chicago, the lone statistically significant determinant of high school choice, whether a charter middle school also offers grade 9 , cannot be excluded from any of the outcome equations. Thus, for Chicago, we must rely on the non-

\footnotetext{
${ }^{16}$ Formally, a test of exclusion restrictions requires an overidentified system where all instruments are valid. However, it is common practice in the empirical literature to conduct the sort of informal tests we use here.
} 
linearity of the bivariate probit for identification for the outcomes of high school graduation and college attendance.

Table A.2. Wald Tests of Exclusion Restrictions in Attainment Equations

\begin{tabular}{|c|c|c|c|c|}
\hline \multirow[b]{2}{*}{ Model/Exclusion } & \multicolumn{2}{|l|}{ Florida } & \multicolumn{2}{|c|}{ Chicago } \\
\hline & $\begin{array}{l}\text { Chi-Squared } \\
\text { (d.f.) }\end{array}$ & $\begin{array}{l}\text { Prob. } \\
\text { Value }\end{array}$ & $\begin{array}{l}\text { Chi-Squared } \\
\text { (d.f.) }\end{array}$ & $\begin{array}{l}\text { Prob. } \\
\text { Value }\end{array}$ \\
\hline $\begin{array}{l}\text { High School Graduation } \\
\text { - All Variables }\end{array}$ & $\begin{array}{l}31.46 \\
(5)\end{array}$ & 0.0000 & $\begin{array}{l}61.57 \\
(5)\end{array}$ & 0.0000 \\
\hline $\begin{array}{l}\text { High School Graduation } \\
\text { - Minimum Distance Var. }\end{array}$ & $\begin{array}{l}12.75 \\
(2)\end{array}$ & 0.0017 & $\begin{array}{l}6.65 \\
(2)\end{array}$ & 0.0359 \\
\hline $\begin{array}{l}\text { High School Graduation } \\
\text { - No. Charters, No. Privates }\end{array}$ & $\begin{array}{l}4.24 \\
(2)\end{array}$ & 0.1199 & $\begin{array}{l}11.40 \\
(2)\end{array}$ & 0.0033 \\
\hline $\begin{array}{l}\text { High School Graduation } \\
\text { - "Offer G9" }\end{array}$ & $\begin{array}{l}6.38 \\
(1)\end{array}$ & 0.0115 & $\begin{array}{l}41.71 \\
(1)\end{array}$ & 0.0000 \\
\hline $\begin{array}{l}\text { High School Graduation } \\
\text { - No. Charters, No. Privates, "Offer G9" }\end{array}$ & $\begin{array}{l}16.36 \\
(3)\end{array}$ & 0.0010 & $\begin{array}{l}55.40 \\
(3)\end{array}$ & 0.0000 \\
\hline $\begin{array}{l}\text { College Attendance } \\
\text { - All Variables }\end{array}$ & $\begin{array}{l}14.72 \\
(5)\end{array}$ & 0.0116 & $\begin{array}{l}30.44 \\
(5)\end{array}$ & 0.0000 \\
\hline $\begin{array}{l}\text { College Attendance } \\
\text { - Minimum Distance Var. }\end{array}$ & $\begin{array}{l}9.04 \\
(2)\end{array}$ & 0.0109 & $\begin{array}{l}9.31 \\
(2)\end{array}$ & 0.0095 \\
\hline $\begin{array}{l}\text { College Attendance } \\
\text { - No. Charters, No. Privates }\end{array}$ & $\begin{array}{l}7.54 \\
(2)\end{array}$ & 0.0231 & $\begin{array}{l}0.06 \\
(2)\end{array}$ & 0.9698 \\
\hline $\begin{array}{l}\text { College Attendance } \\
\text { - "Offer G9" }\end{array}$ & $\begin{array}{l}0.85 \\
(1)\end{array}$ & 0.3554 & $\begin{array}{l}10.95 \\
(1)\end{array}$ & 0.0009 \\
\hline College Attendance & 7.59 & 0.0553 & 21.52 & 0.0001 \\
\hline
\end{tabular}


- No. Charters, No. Privates, "Offer G9"

Persist in college at least 2 years

16.14

0.0065

26.82

0.0000

- All Variables

(5)

(5)

Persist in college at least 2 years

2.06

0.3562

7.34

0.0148

- Minimum Distance Var.

(2)

(2)

Persist in college at least 2 years

6.57

0.0374

0.073

0.9421

- No. Charters, No. Privates

(2)

(2)

Persist in college at least 2 years

- "Offer G9"

0.03

(1)

2.28

(3)
11.81

(1)

Persist in college at least 2 years

$2.28 \quad 0.5163$

22.18

- Minimum Distance Var., "Offer G9"

12.33

(3)

0.0063

20.66

0.0001

- No. Charters, No. Privates, "Offer G9"

(3)

0.0001

0.0007

(3)

\section{Earnings 10 Years After Grade 8}

- All Variables

Earnings 11 Years After Grade 8

- All Variables

Earnings 12 Years After Grade 8

- All Variables
0.73

(5)

2.02

0.0777

NA

(5)

1.45

0.2082

NA

(5)
NA

0.5985

A

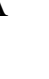




\section{B. Bivariate Probit Estimates of Impacts on Persistence in College}

Using bivariate probit regressions, we estimate the effect of attending charter high schools on educational attainment, accounting for the potential impact of unobservable factors on both high school choice and educational attainment. In Table A.3, we present the bivariate probit estimates of the effect of charter high school attendance on high school graduation, college entry within six years, and persistence in college for at least two years. The bivariate estimates are in the same direction as the univariate estimates in Table 3 and generally statistically significant across the measures; this suggests that our results are robust to the bivariate approach. As mentioned in the main text, however, for both Florida and Chicago, the correlation between error of the regression equation and the error of the selection equation (measured by rho) is not statistically significant for any of the three outcomes. Therefore, we fail to reject the null hypothesis that high school choice (conditional on attending a charter middle school and all the controls for observables) is exogenous. Put differently, we find no evidence that unobservable factors driving high school choice are affecting educational attainment and no evidence that the univariate probit estimates are unbiased.

\section{Table A.3. Bivariate Probit of Estimates of the Effects of Charter High School Attendance on Educational Attainment (Coefficient Estimates Are Marginal Effects)}

\begin{tabular}{|c|c|c|c|c|}
\hline \multirow{3}{*}{ Estimation Method } & \multicolumn{2}{|c|}{ Florida } & \multicolumn{2}{|c|}{ Chicago } \\
\hline & Rho & Marginal Effect & Rho & Marginal Effect \\
\hline & \multicolumn{4}{|c|}{ Receiving a Standard High School Diploma (within 5 years) } \\
\hline Univariate Probit & 0.000 & $\begin{array}{l}0.109^{* *} \\
(0.027)\end{array}$ & 0.000 & $\begin{array}{c}0.074^{*} \\
(0.035)\end{array}$ \\
\hline \multirow[t]{2}{*}{ Bivariate Probit } & $\begin{array}{l}-0.090 \\
(0.122)\end{array}$ & $\begin{array}{c}0.109^{+} \\
(0.061)\end{array}$ & $\begin{array}{l}-0.084 \\
(0.120)\end{array}$ & $\begin{array}{c}0.154^{* *} \\
(0.049)\end{array}$ \\
\hline & \multicolumn{4}{|c|}{ Attending a Two- or Four-Year College (within 6 years) } \\
\hline Univariate Probit & 0.0000 & $\begin{array}{l}0.099 * * \\
(0.030)\end{array}$ & 0.000 & $\begin{array}{l}0.109 * * \\
(0.042)\end{array}$ \\
\hline Bivariate Probit & -0.280 & $0.257^{+}$ & -0.087 & $0.121^{*}$ \\
\hline
\end{tabular}




\begin{tabular}{cccc}
$(0.287)$ & $(0.150)$ & $(0.198)$ & $(0.056)$ \\
\hline \multicolumn{4}{c}{ Persist in Any College at Least Two Consecutive Years } \\
\hline 0.000 & $0.126^{* *}$ & 0.000 & 0.066 \\
& $(0.045)$ & -0.062 & $(0.046)$ \\
0.044 & 0.086 & $0.090^{+}$ \\
$(0.258)$ & $(0.168)$ & $(0.098)$ & $(0.049)$ \\
\hline
\end{tabular}

Note: Standard errors adjusted for clustering at the school level are in parentheses. Coefficient estimates are marginal effects. For the bivariate probit estimates, the reported standard errors equal the marginal effects divided by the bivariate probit z-scores (adjusted for clustering at the school level). The five-mile radius equation reported in Appendix Table A.1 is used to predict charter high school attendance in the bivariate probit equations. Following the exclusion-restriction tests in Appendix Table A.2, only the number of proximate private schools and the number of proximate charter schools are excluded from the graduation equation for Florida, and none of the school choice determinants is excluded from the graduation equation for Chicago. Given the exclusion restriction tests, the distance to the nearest traditional public high school, the distance to the nearest charter high school, and whether a school offers grade 9 are excluded from the college attendance equation for Florida. For Chicago, the number of proximate private schools and the number of proximate charter schools are excluded from the college attendance equation. In the two-year persistence equation, the distance to the nearest traditional public high school, the distance to the nearest charter high school, and whether a school offers grade 9 are excluded. In Chicago, the number of proximate private schools and the number of proximate charter schools are excluded.

\section{IV Estimates of Earnings}

As with the estimates of educational attainment, we examine whether the OLS estimates of the impact of charter high school attendance on earnings are biased. This is done by comparing IV estimates of the earnings equation, which should be consistent even if high school choice is endogenous, with the OLS estimates, which will only be consistent under the null of exogeneity. As noted in the main text, because we are clustering the standard errors in our analysis of earnings, we cannot use the standard Hausman test. Instead, the relevant test with clustering is the $\mathrm{C}$ test, which suggested that the OLS estimates should be unbiased and we can use the OLS analyses as our primary means of estimating the effects.

Table A.4 presents IV estimates of the earnings equation. Overall, the estimates are substantively consistent with the OLS estimates in Table 6 of the main text, because all the coefficient estimates are positive (with larger magnitudes than the OLS estimates) and generally statistically significant when aggregating across cohorts (last row). As with the OLS estimates, the IV estimates for the individual cohorts are generally positive, but less frequently significant 
because of the reduced power relative to the aggregate analysis. The $\mathrm{C}$ tests result in $p$-values ranging from 0.15 to 0.56 and thus fail to reject the null hypothesis that the OLS estimates are consistent in all cases. This reinforces confidence in the OLS estimates presented in Table 6.

Table A.4. IV Estimates of the Effect of Florida Charter High School Attendance on Annual Earnings, by Cohort and by Years Since Beginning Grade 8

Years Since Beginning Grade 8

\begin{tabular}{|c|c|c|c|c|}
\hline Cohort & 10 Years & 11 Years & 12 Years & $\begin{array}{r}\text { Max. of } 10,11 \\
\text { and } 12 \text { Years }\end{array}$ \\
\hline $\begin{array}{l}\text { G8 in } 1997 \text { and G8 } \\
\text { in } 1998\end{array}$ & $\begin{array}{c}-405.60 \\
(3,729.93) \\
{[\mathrm{N}=272]}\end{array}$ & $\begin{array}{c}937.86 \\
(4,433.32) \\
{[\mathrm{N}=254]}\end{array}$ & $\begin{array}{c}2902.49 \\
(6,332.20) \\
{[\mathrm{N}=248]}\end{array}$ & $\begin{array}{c}3511.07 \\
(4,812.49) \\
{[\mathrm{N}=324]}\end{array}$ \\
\hline G8 in 1999 & $\begin{array}{c}3,503.64 * \\
(1,399.46) \\
{[N=728]}\end{array}$ & $\begin{array}{c}4,840.06^{* *} \\
(1,743.59) \\
{[\mathrm{N}=717]}\end{array}$ & $\begin{array}{c}6,574.00^{* *} \\
(2,410.70) \\
{[\mathrm{N}=713]}\end{array}$ & $\begin{array}{c}7,243.85^{* *} \\
(2,156.20) \\
{[\mathrm{N}=897]}\end{array}$ \\
\hline G8 in 2000 & $\begin{array}{c}790.14 \\
(1,814.58) \\
{[\mathrm{N}=1053]}\end{array}$ & $\begin{array}{c}1,859.18 \\
(2,217.94) \\
{[\mathrm{N}=1059]}\end{array}$ & & $\begin{array}{c}2,314.51 \\
(2,079.58) \\
{[\mathrm{N}=1,227]}\end{array}$ \\
\hline All & $\begin{array}{c}1,782.57 \\
(1,388.83) \\
{[\mathrm{N}=2053]}\end{array}$ & $\begin{array}{c}3,066.37^{*} \\
(1,564.61) \\
{[\mathrm{N}=2030]}\end{array}$ & $\begin{array}{c}6,310.76^{* *} \\
(1,965.74) \\
{[\mathrm{N}=961]}\end{array}$ & $\begin{array}{c}4,294.73 * * \\
(1,619.70) \\
{[\mathrm{N}=2,448]}\end{array}$ \\
\hline $\begin{array}{l}p \text {-Value for C Test } \\
\text { of Endogeneity of } \\
\text { Charter High } \\
\text { School Attendance }\end{array}$ & 0.559 & 0.479 & 0.159 & 0.147 \\
\hline
\end{tabular}

Note: Standard errors adjusted for clustering at the school level are in parentheses. + significant at $10 \%$; * significant at $5 \% ; * *$ significant at $1 \%$. Sample size in brackets. 


\section{References}

Abdulkadiroğlu, A., Angrist, J. D., Dynarski, S. M., Kane, T. J., \& Pathak, P. A. (2011). Accountability and flexibility in public schools: Evidence from Boston's charters and pilots. The Quarterly Journal of Economics, 126(2), 699-748.

Altonji, J. G., Elder, T. E, \& Taber, C. (2005). Selection on observed and unobserved variables: Assessing the effectiveness of Catholic schools. Journal of Political Economy, 113, 151184.

Angrist, J. D., Cohodes, S. R., Dynarski, S. M., Pathak, P. A., \& Walters, C. D. (2013). Charter schools and the road to college readiness: The effects on college preparation, attendance and choice. Boston: Boston Foundation and NewSchools Venture Fund.

Angrist, J. D., Pathak, P. A., \& Walters, C. R. (2011). Explaining charter school effectiveness. Cambridge, MA: National Bureau of Economic Research.

Barrow, L, Claessens, A., \& Whitmore Schanzenbach, D. (2009). "The impact of small schools in Chicago: Assessing the effectiveness of Chicago's small high school initiative." Unpublished manuscript, University of Chicago.

Baum, C. F., Schaffer, M. E., \& Stillman, S. (2003). Instrumental variables and GMM: Estimation and testing. Stata Journal, 3(1), 1-31.

Berkner, L., \& Choy, S. (2008). Descriptive summary of 200304 beginning postsecondary students: Three years later. (NCES 2008-174). Washington, DC: U.S. Department of Education, Institute of Education Sciences, National Center for Education Statistics.

Bettinger, E. P., Long, B. T., Oreopoulos, P., \& Sanbonmatsu, L. (2012). The Role of simplification and information in college decisions: Results from the H\&R Block FAFSA experiment. Quarterly Journal of Economics, 127(3), 1205-1242

Bifulco, R., \& Ladd, H. F. (2006). The impact of charter schools on student achievement: Evidence from North Carolina. Journal of Education Finance and Policy, 1(1), 50-90.

Bifulco, R., Cobb, C., \& Bell, C. (2009). Can interdistrict choice boost achievement: Evidence from Connecticut's interdistrict magnets. Educational Evaluation and Policy Analysis, 31(4), 323-345.

Bloom, H., \& Unterman, R. (2013). Sustained progress: New findings about the effectiveness and operation of small public high schools of choice in New York City. New York: MDRC. Retrieved August 28, 2013, from http://www.mdrc.org/sites/default/files/sustained_progress _FR_0.pdf. 
Booker, T. K., Gilpatric, S. M., Gronberg, T. J., \& Jansen, D. W. (2007). The impact of charter school student attendance on student performance. Journal of Public Economics, 91(5-6), 849-876.

Booker, K., Sass, T., Gill, B., \& Zimmer, R. (2011). The effects of charter high schools on educational attainment. Journal of Labor Economics, 29(2), 377-415.

Butler, J. S., Carr, D., Toma, E. F., \& Zimmer, R. (2013). Choice in a world of new school types. Journal of Policy Analysis and Management, 32(4), 785-806.

Chetty, R., Friedman, J., \& Rockoff, J. (2011). The long-term impacts of teachers: Teacher value-added and student outcomes in adulthood. NBER Working Paper 17699. Retrieved November 1, 2013, from http://www.nber.org/papers/w17699.pdf?new window=1.

Chingos, M. M., \& Peterson, P. E. (2012). The effects of school vouchers on college enrollment: Experimental evidence from New York City. Washington, DC: Brown Center on Education Policy at Brookings and Harvard Kennedy School Program on Education Policy and Governance.

Davis, D. H., \& Raymond, M. E. (2012). Choices for studying choice: Assessing charter school effectiveness using two quasi-experimental methods. Economics of Education Review, 31, $225-236$.

Day, J., \& Newburger, E. C. (2002, July). The big payoff: Educational attainment and synthetic estimates of work-life earnings, Current Population Reports (pp. 23-210). Washington, DC: U.S. Census Bureau. Available: http://www.census.gov/prod/2002pubs/p23-210.pdf

Deming, D. J., Hastings, J. S., Kane, T. J., \& Staiger, D. O. (2013). School choice, school quality, and postsecondary attainment. American Economic Review, forthcoming.

Dobbie, W., \& Fryer, R. G., Jr. (2011). Getting beneath the veil of effective schools: Evidence from New York City. Working Paper 17632. Cambridge, MA: National Bureau of Economic Research.

Dobbie, W., \& Fryer, R. G., Jr. (2013). The medium-term impacts of high-achieving charter schools on non-test score outcomes. Working Paper. Princeton, NJ: Princeton University.

Evans, W. N., \& Schwab, R. M. (1995). Finishing high school and starting college: Do Catholic schools make a difference. The Quarterly Journal of Economics, 110(3), 941-974.

Fairlie, Robert W. (2005). An extension of the Blider-Oaxaca decomposition technique to logit and probit models. Journal of Economic and Social Measurement, 30, 305-316.

Furgeson, J., Gill, B., Haimson, J., Killewald, A., McCullough, M., Nichols-Barrer, I.,...Lake, R. (2012, January). Charter-school management organizations: Diverse strategies and diverse student impacts. Cambridge, MA: Mathematica Policy Research. 
Gleason, P., Clark, M., Tuttle, C. C., \& Dwoyer, E. (2010). The evaluation of charter school impacts: Final report. (NCEE 2010-4029). Washington, DC: U.S. Department of Education, Institute of Education Sciences, National Center for Education Evaluation and Regional Assistance.

Glomm, G., Harris, D., Lo, T. (2005). “Charter school location.” Economics of Education Review 24:451-57.

Grogger, J., \& Neal, D. (2000). Further evidence on the effects of Catholic secondary schooling. Brookings-Wharton Papers on Urban Affairs, 151-201.

Hanushek, E. A., Kain, J. F., Rivkin, S. G., \& Branch, G. F. (2007). Charter school quality and parental decision making with school choice. Journal of Public Economics, 91, 823-848.

Heckman, J. J. (1979). Sample selection bias as a specification error. Econometrica, 47, 153161.

Hoxby, C. M., \& Murarka, S. (2007). Charter schools in New York City: Who enrolls and how they affect their students' achievement. Cambridge, MA: National Bureau of Economic Research. Retrieved November 5, 2008, from http://www.nber.org/ $\sim$ schools/charterschoolseval/nyc charter schools technical report july2007.pdf.

Hoxby, C. M., \& Rockoff, J. E. (2004). The impact of charter schools on student achievement. Unpublished paper. Department of Economics, Harvard University.

Lee, David S. (2009). Training, wages, and sample selection: Estimating sharp bounds on treatment effects. Review of Economic Studies, 76, 1071-1102.

Neal, D. (1997). The effects of Catholic secondary schooling on educational achievement. Journal of Labor Economics, 15, 98-123.

Richburg-Hayes, et al. (2009). Rewarding persistence: Effects of a performance-based scholarship program for low-income parents (Academic). MDRC, Access: http://www.mdrc.org/sites/default/files/Rewarding\%20Persistence\%20ES.pdf

Sander, W., \& Krautman, A. C. (1995). Catholic schools, dropout rates and educational attainment. Economic Inquiry, 33, 217-233.

Sass, T. R. (2006). Charter schools and student achievement in Florida. Education Finance and Policy, 1(1), 91-122.

Tuttle, C. T., Gleason, P., \& Clark, M. (2012). Using lotteries to evaluate schools of choice: Evidence from a national study of charter schools. Economics of Education Review, 31, 237-253.

Tuttle, C. T., Gill, B., Gleason, P., Knechtel, V., Nichols-Barrer, I., \& Resch, A. (2013). "KIPP middle schools: Impacts on achievement and other outcomes." Washington, DC: Mathematica Policy Research, February 27, 2013. 
Wolf, P. J., Kasida, B., Gutmann, B., Puma, M., Eissa, N., \& Rizzo, L. (2013). School vouchers and student outcomes: Experimental evidence from Washington, DC. Journal of Policy Analysis and Management, 32(2), 246-270.

Wooldridge, J. M. (2002). Econometric analysis of cross section and panel data. Cambridge, MA: MIT Press.

Zimmer, R., \& Buddin, R. (2006). Charter school performance in urban districts. Journal of Urban Economics, 60(2), 307-326.

Zimmer, R., Buddin, R., Chau, D., Gill, B., Guarino, C., Hamilton, L.,...Brewer, D. (2003). Charter school operation and performance: Evidence from California. MR-1700. Santa Monica, CA: RAND.

Zimmer, R., Gill, B., Booker, K., Lavertu, S., Sass, T., \& Witte, J. (2009). Charter Schools in Eight States: Effects on achievement, attainment, integration, and competition. MG-869. Pittsburgh: RAND.

Zimmer, R., Gill, B., Booker, K., Lavertu, S., \& Witte, J. (2012). Examining charter school achievement in seven states. Economics of Education Review, 31(2), 213-224.

Zimmer, R., \& Engberg, J. (2013). Can broad inferences be drawn from lottery analyses of school choice programs? An exploration of appropriate sensitivity analyses. Working Paper. Nashville, TN: Vanderbilt University. 